\title{
NATIONAL INTELLECTUAL CAPITAL TAXONOMY
}

\author{
Grażyna MICHALCZUK ${ }^{1}$, Julita FIEDORCZUK ${ }^{2}$ \\ ${ }^{1,2}$ Bialystok University, Biatystok, Poland \\ Corresponding author's e-mail: fiedorczukjulita@uwb.edu.pl
}

\begin{abstract}
The concept of national intellectual capital (NIC) is in its early stage of development. NIC has a complicated and heterogeneous nature with NIC models displaying varying levels of aggregation and structure as well as inconsistent accuracy. As a result, the authors' standpoints differ according to definition and NIC taxonomy. The aim of this article is to analyze NIC taxonomy and to organize and classify the scattered and often inadvertent intangible generators of the country's wealth. The results of the research confirm a lack of a generally accepted definitional and taxonomic approach to NIC making a search for an acceptable solution necessary since without it the measurement and comparability of results or even the management and control of the intellectual capital of the country will not be possible. Besides contemplating the existing approaches of NIC division, the authors create their own NIC taxonomy and describe its components by presenting an original understanding of NIC components. This is extremely important because the subject of NIC has not yet been scientifically sufficiently exhausted.
\end{abstract}

Keywords: Development capital, human capital, national intangible assets, national intellectual capital (NIC), national wealth, relation capital, social capital, structural capital.

JEL Classification: E01, E22, J24, O11, O34.

\section{INTRODUCTION}

The concept of intellectual capital has been propagated as a result of the transition of the world economy from the industrial age based on the use of traditional production factors to knowledge-based economy (Michalczuk, 2013). Intellectual capital is a category that reflects the intangible resources contributing towards the value of a company. This is the context of the perception of intellectual capital within the microeconomic perspective. Significant works about intellectual capital as a creator of value have been written by Sveiby, Sullivan, Edvinson, Onge, Stewart, Petrash, and Lev (Fiedorczuk \& Michalczuk, 2016a).

The development of a knowledge-based economy created a need to displace the concept of intellectual capital also in relation to macroeconomics. In the 1990s, intellectual capital - intangible resources - was recognized as a determinant of a country's wealth (Labra \& Sanchez, 2013). During this time, through the analysis of Sweden, a first attempt to measure national intellectual capital (NIC) on a national scale was undertaken. The brief history of the concept of intellectual capital makes it an attractive subject for scientific research because the theme is still unfathomable, particularly from the macroeconomic perspective. Specific features 
of intellectual capital related primarily to the lack of a physical dimension (financial dimension) create not only definitional difficulties but also ones concerning its taxonomy. This fact has been reflected in diverse approaches to NIC structure recognition with individual authors focusing on its many aspects (Michalczuk, 2013).

The present article aims to analyze NIC from the perspective of its taxonomy. The results of the research will allow the organization of available economic knowledge as well as the creation of new knowledge, filling a research gap currently existing in this regard. Other than contemplating the existing approaches to NIC taxonomy, the authors also intend to attempt to explain their own conceptual model of NIC and present an original understanding of NIC components.

\section{METHODS AND PROCEDURES}

To achieve the aim of the research it was necessary to consider selected approaches of some authors. The work was based on literature studies consisting of reviewing main achievements of science in structuring the national intellectual capital.

The article was written on the basis of a literature analysis. The authors made a study of sixteen theoretical and empirical works. On the basis of these studies, they were able to show divisions created by other researchers, evaluate existing solutions and develop their own conceptual model.

\section{APPROACHES TO DEFINING NATIONAL INTELLECTUAL CAPITAL}

Scientific literature does not abound in publications dealing with the subject of national intellectual capital. The main cause of this is the concept's brief history in respect to the macroeconomic perspective even though intellectual capital has always existed in people, businesses, communities, and countries. Due to the microeconomic scale of the initial scientific considerations of the subject, most available definitions focus on individual objects such as businesses and organizations creating a large list of publications. Although the term was first used some time ago, a clear and commonly accepted definition of both its micro- and macroeconomic concepts has not yet been developed and the process of improving existing explanations is ongoing.

Definitions of NIC models do not cover all approaches to the conceptualization of national intellectual capital but rather point to the understanding of intellectual capital in the macroeconomic perspective as well as determine its frame. They are, however, characterized by terminological and conceptual divergence, which is undoubtedly the result of individual authors' attempt to understand the same category of intellectual capital or its large dichotomous possibilities. As emphasized by Brennan and Connell, differences are the result of different levels of aggregation of NIC and the dual perception of the essence of the term (Brennan \& Connell, 2000). This duality can be seen in two basic aspects: the static and the dynamic ways of defining it. From the static point of view, intellectual capital is considered 
in the context of its components. In terms of the dynamic perspective, intellectual capital reflects not only the identified intangible assets as the potential of an economy but also the consequences of interrelationships and dependencies between its components (the effect of the transformation and flow of useful knowledge at the macroeconomic level). Being a dynamic variable, intellectual capital is subject to transformation and constitutes a component which determines value creation (Michalczuk, 2013).

The analyzed conceptual models have clearly evolved over time. Due to the microeconomic sources of NIC theory, its older definitions are more similar to explanations made at the company level. They differ only in that they expand the scope of intangible resources of the company to the national level (Sweden, Israel).

In this context, Malhotra (2003) proposes a relatively revolutionary definition of NIC. His understanding of NIC contained a new idea concerning the division of a country into diverse, in regard to homogeneity and size, parts: individuals, companies, institutions, and government. Due to the theoretical nature of his work, the greatest share of practical function is attributed to a model developed by Bontis (Michalczuk \& Fiedorczuk, 2017).

Despite some differences in the approaches to defining NIC, these definitions are, in a general sense, similar to one another (Käpylä, Kujansivu \& Lönnqvist, 2012) and share the following features:

- NIC is an invisible, intangible and hidden form of a country's capital (intangible assets);

- NIC resources mainly lie in individuals: in their knowledge, wisdom, experience, skills, or creativity. In some definitions (especially those formulated after 2003), resources are classified as parts of larger groups (such as enterprises, communities, institutions, administrative units, regions, or governments);

- the useful nature of intellectual capital is assumed (often with statements using future growth, potential financial returns, potential for wealth creation, future nourishment, foundation for future earning ability, cultivation of future well-being);

- the essence of NIC is explained using terms relating to the present (current wealth, potential, sources, comparative advantages) and the future (future growth, future wealth, future benefits);

- authors use static expressions to define NIC (wealth, benefits, welfare, quality of life, value), and dynamic expressions (improvement of the quality of life, future growth, benefits production, wealth creation).

The diversity of NIC conceptual models also depends on sample size, the specific character of the object being examined, the availability of data, and other publications connected with this subject. Most of the studied conceptual approaches rely on the Skandia model (Scandia Navigator) developed by Leif Edvinsson who focuses on the two main components (human capital and structural capital) of NIC. The addendum to the annual report published in 1994 by Skandia*, where this new solution was presented, should be considered a breakthrough achievement

* Swedish insurance enterprise "Skandia AFS". 
systematizing the knowledge about intellectual capital and reporting the "hidden value" of an organization as well as an inspiration for more in-depth research within this field for other authors (Fiedorczuk \& Michalczuk, 2016b).

Recently, many definitions of NIC have been formulated with new interpretations constantly being developed. Although these interpretations sometimes differ considerably, very often they also exhibit common features, mainly on account of being modified or more precise versions of already existing definitions.

\section{ANALYSIS OF DIVISION CONCEPTS OF NATIONAL INTELLECTUAL CAPITAL}

Definitions of national intellectual capital which have been developed so far differ in their approach as to the very understanding of this category. There is also a lack of unanimity in regard to the components of NIC. As a result, the internal structure of intellectual capital is recognized by the individual authors differently. The diversity of concepts defining and describing intellectual capital shows a need for the organization of approaches to NIC categorization (Michalczuk, 2013).

"C. Stenfelt interpreted human capital using variables describing the level of education of residents, their quality of life, their average life expectancy, infant mortality, crime rates, and their attitudes towards smoking" (Amidon, 2002). Market capital was characterized utilizing statistics relating to tourism, standards of honesty, and balance of trade. Process capital was described employing information about service-producing organizations, the share of public consumption in gross domestic product (GDP), business leadership, and the level of computerization. Spending on research and development $(R \& D)$ in relation to GDP, the amount of the original start-ups, trademarks and patents were considered to be an expression of renewal and development capital (Amidon, 2002).

"A. Rembe, in turn, assessed the components of national intellectual capital from the perspective of the attractiveness of Sweden to foreign investment and the proposed strategic plan for the development of individual components of intellectual capital in relation to Sweden" (Edvinsson \& Lin, 2012).

A similar structure of the intellectual capital of the country was assumed by Pasher \& Shachar $(2004,2007)$. The conceptual framework of these reports was modeled on a division developed by Edvinsson - "Skandia Model" $\dagger$. The first distinguished component is human capital. It contains the knowledge, wisdom, experience, intuition, and the ability of individuals to carry out national tasks and objectives. Market capital reflects national intellectual assets and markets, which are maintained through international contacts, while process capital refers to the cooperation and transfer of knowledge based on structural intellectual assets. Renewal and development capital relates to the national capacity to develop sophisticated solutions and is the added value of the country as well as determines future growth. (Pasher \& Shachar, 2004, 2007).

Malhotra proposed his own theoretical conceptual model of national knowledge

\footnotetext{
${ }^{\dagger}$ In 1994, Skandia began to publish the statements of intellectual capital as a supplement of financial accounting reports. (Fiedorczuk \& Michalczuk 2016b)
} 
assets. He used the structure of NIC developed by Edvinsson and Malone (1997) and divided NIC into two main components: human capital, and structural capital. He defined human capital as a combination of knowledge, skills, innovation and the ability of individuals to carry out national tasks such as the propagation of values, culture, and philosophy. This capital also includes wisdom, knowledge, skills, intuition, and the ability of citizens to create value. Human capital is in the possession of individuals. On the other hand, structural capital is in contrast to human capital and may be owned by the state and become an object of exchange. Malhotra differentiates market and organizational capital from structural capital. In Malhotra's conceptual model, market capital refers to trading and market relationships maintained by the state within the framework of global markets (Malhotra, 2003).

Bontis (like Malhotra, 2003; Rembe \& ISA, 1999; and Stenfelt et al., 1996) in his concept for a model of national knowledge assets duplicates the taxonomy of Edvinsson and Malone (1997) dividing the national knowledge assets of a country into two main units: human capital, and structural capital. Structural capital is then divided into market capital and organizational capital which consists of process capital and renewal capital (Bontis, 2004).

Andriessen and Stam divide national intellectual capital into human, structural and relational components assuming three perspectives for their assessment: past, present, and future. Andriessen and Stam's solution is seen as particularly innovative since it aptly expresses the dependence of the present state of national intellectual capital on its past and future situations (Andriessen \& Stam, 2005; 2008).

In their diagnosis of Thailand's NIC, Phusavat, Comepa, Sitko-Lutek, and Ooi assumed that it is made up of human capital, market (customer) capital, process (information) capital, and innovation capital. The accent that made this approach of NIC assessment unique was its division of organizational capital into the capital of innovation and capital of process/information (Phusavat et al., 2012). It should also be emphasized that the structure of organizational capital of the Thailand model is derived from the Skandia Value Scheme. Definitions of these components adopted for the need of this article show that innovation capital should clearly be interpreted using renewal and development capital (Fiedorczuk \& Michalczuk, 2016b).

Approaches of other authors in dividing NIC are presented in Table 1.

Table 1. NIC components and definitions

\begin{tabular}{|l|l|}
\hline $\begin{array}{l}\text { NIC components } \\
\text { (kind of capital) }\end{array}$ & \multicolumn{1}{|c|}{ Definition } \\
\hline Węziak, D. (2007) & \\
\hline Human & $\begin{array}{l}\text { Includes knowledge, skills, and abilities. So-called soft skills encompass } \\
\text { teamwork, persistence, flexibility, communication, and skills that seem to } \\
\text { be the most important. }\end{array}$ \\
\hline Structural & $\begin{array}{l}\text { "Non-human repositories of knowledge are expressed in the form of } \\
\text { technology, information and communication systems and are represented } \\
\text { by hardware, software, databases, laboratories or organizational structures } \\
\text { that uphold and extensificate the effects of human capital work". }\end{array}$ \\
\hline
\end{tabular}




\begin{tabular}{|c|c|}
\hline Relation & $\begin{array}{l}\text { "Intellectual capital embedded in national intra-community relationships } \\
\text { representing national capacities and success in ensuring the attractiveness } \\
\text { and competitiveness of the needs of its international clients compared to } \\
\text { other countries" (Bontis, 2004), as well as the quality of relations of the } \\
\text { country's inhabitants. }\end{array}$ \\
\hline Renewal & $\begin{array}{l}\text { "Future intellectual wealth of the country" which reflects the country's } \\
\text { ability to innovate (Bontis, 2004). It is reflected in real research and } \\
\text { development investment, level of innovation, process modernization, and } \\
\text { innovation adaptation. }\end{array}$ \\
\hline \multicolumn{2}{|c|}{ Zespół Doradców Strategicznych Prezesa Rady Ministrów* (2008) } \\
\hline Human & $\begin{array}{l}\text { The potential accumulated in all citizens expressed in their education, life } \\
\text { experience, attitudes and skills which is able to improve the current and } \\
\text { future well-being of Poland. }\end{array}$ \\
\hline Structural & $\begin{array}{l}\text { The potential accumulated in tangible components of the infrastructure of } \\
\text { the national system of education and innovation: educational, scientific, } \\
\text { research, ICT infrastructure, and intellectual property. }\end{array}$ \\
\hline Social & $\begin{array}{l}\text { The potential accumulated in the society in the form of norms of conduct, } \\
\text { trust and commitment, which, supporting cooperation and exchange of } \\
\text { knowledge, contributes to the growth and welfare of the country. }\end{array}$ \\
\hline Relation & $\begin{array}{l}\text { The potential associated with the external image of the country, the level } \\
\text { of its integration with the global economy, its attractiveness for foreign } \\
\text { customers - business partners, investors, or tourists. }\end{array}$ \\
\hline \multicolumn{2}{|c|}{ Węziak-Białowolska, D. (2010) } \\
\hline Human & $\begin{array}{l}\text { Knowledge and education, skills and abilities possessed by people and } \\
\text { characterizing their personality associated with entrepreneurship, tendency } \\
\text { to innovate and with the desire to acquire knowledge through formal and } \\
\text { informal education. }\end{array}$ \\
\hline Social & $\begin{array}{l}\text { A set of social and legal norms as well as jointly shared values, customs } \\
\text { shaping social and economic relations, expressed primarily at the level of } \\
\text { social trust and in the correct quantity and quality of formal and informal } \\
\text { interpersonal networks and relationships between widely understood } \\
\text { organizations, institutions, and enterprises. }\end{array}$ \\
\hline Structural & $\begin{array}{l}\text { Infrastructure (set of public tools satisfying social, educational and cultural } \\
\text { needs of the population) and technical infrastructure. }\end{array}$ \\
\hline Development & $\begin{array}{l}\text { The ability to innovate which is expressed by the level of current } \\
\text { investment and future investment opportunities into research and } \\
\text { development as well as the level of exchange and application of } \\
\text { knowledge to make the best use of that potential and shape the future } \\
\text { wealth of the country. }\end{array}$ \\
\hline \multicolumn{2}{|c|}{ Edvinsson, L. \& Lin C. Y.Y. (2008, 2011) } \\
\hline Human & $\begin{array}{l}\text { Knowledge about facts, the law and principles as well as knowledge } \\
\text { relating to teamwork and other communications skills, wisdom, } \\
\text { experience, intuition and the ability of individuals in realizing national } \\
\text { goals. It includes the nation's culture and philosophy. Education is the } \\
\text { foundation of human capital. }\end{array}$ \\
\hline Market & $\begin{array}{l}\text { National capabilities in providing attractive, competitive incentives for } \\
\text { meeting the needs of international customers and the country's }\end{array}$ \\
\hline
\end{tabular}

In English: Strategic Advisors of the President of the Minister's Council. 


\begin{tabular}{|c|c|}
\hline & $\begin{array}{l}\text { achievements in foreign relations, including the export of high quality } \\
\text { products, services and knowledge sharing with the rest of the world. }\end{array}$ \\
\hline Process & $\begin{array}{l}\text { Non-human resources of national knowledge that are embedded in country } \\
\text { infrastructure and facilitate corporate competitiveness, government } \\
\text { efficiency, intellectual property rights protection, and the availability of } \\
\text { capital. }\end{array}$ \\
\hline Renewal & $\begin{array}{l}\text { The nation's future intellectual wealth and its capability for innovation that } \\
\text { sustains a nation's competitive advantage. }\end{array}$ \\
\hline \multicolumn{2}{|c|}{ Navarro, J. L. A., Ruiz, V. R. L. \& Peña D. N. (2014) } \\
\hline Human & $\begin{array}{l}\text { Knowledge, skills, and personal development towards achieving objectives } \\
\text { (qualifications). It also includes cultural values, national labor market } \\
\text { conditions, and resource inflows from workers abroad. }\end{array}$ \\
\hline Structural & $\begin{array}{l}\text { Covers several intangible assets related to the socio-economic framework } \\
\text { of a country, namely, the non-human structure that enables the country to } \\
\text { generate future benefits: business structure, bureaucracy, image, } \\
\text { international market share, technology, innovation, and sustainability. }\end{array}$ \\
\hline Process & $\begin{array}{l}\text { Focusses mainly on a country's private sector structure. It measures } \\
\text { information and management systems, bureaucracy, and organizational } \\
\text { structures. }\end{array}$ \\
\hline Relation or trade & $\begin{array}{l}\text { Captures the quality of balance of trade with positive information about } \\
\text { the export of advanced technology and with negative information about } \\
\text { development aids. }\end{array}$ \\
\hline $\begin{array}{l}\text { Marketing or } \\
\text { image }\end{array}$ & $\begin{array}{l}\text { Concerns the country's domestic as well as foreign image and } \\
\text { international relations. }\end{array}$ \\
\hline $\begin{array}{l}\text { Research, } \\
\text { development, and } \\
\text { innovation }\end{array}$ & $\begin{array}{l}\text { Explicitly measures innovation, research and development possibilities } \\
\text { through investment as well as how efficiently existing resources are } \\
\text { exploited with the information available for countries considered as having } \\
\text { a reduced access to mobile and land connections as well as Internet users. }\end{array}$ \\
\hline $\begin{array}{l}\text { Social and } \\
\text { environmental }\end{array}$ & $\begin{array}{l}\text { Is determined by the social commitment of the social welfare state in } \\
\text { relation to the quality of life of its inhabitants along with activities related } \\
\text { to the environment and sustainable development. }\end{array}$ \\
\hline
\end{tabular}

Note: Developed by the authors on the basis of Edvinsson \& Lin (2011), Navarro et al. (2014), Węziak (2007), Węziak-Białowolska (2010), and Zespół Doradców Strategicznych Prezesa Rady Ministrów (2008).

Definitions of NIC developed until today also differ in terms of its components. As a result, the internal structure of national intellectual capital is interpreted differently by individual authors. The diverse manner in which intellectual capital is defined and described determines the need to organize the academic approach to this field (Michalczuk, 2013).

All conceptual models presented consider human capital to be an essential element of NIC, a fact that is clearly demonstrated in Table 2.

The presented approaches for categorizing NIC belong to the so-called group of academic models $\$$.

\footnotetext{
§In the literature, there are two groups of NIC models ("academic models" - models developed by researchers, and "international organization models" - models developed by international organizations) used to evaluate the intellectual capital of the country (Labra \& Sanchez, 2013).
} 
Table 2. Individual elements of national intellectual capital

\begin{tabular}{|c|c|c|c|c|c|c|}
\hline \multirow{2}{*}{$\begin{array}{c}\text { Author(s), } \\
\text { Publication date }\end{array}$} & \multicolumn{6}{|c|}{ Components of national intellectual capital } \\
\hline & 䓻 & $\sum_{\overline{0}}^{\bar{\Xi}}$ & غ & 氖 & 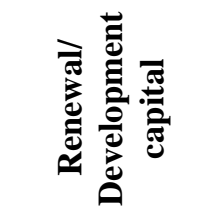 & 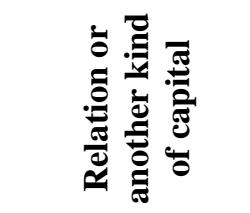 \\
\hline $\begin{array}{l}\text { Stenfelt et al. } \\
\text { (1996) }\end{array}$ & + & & + & + & Renewal & \\
\hline $\begin{array}{l}\text { Rembe \& ISA } \\
\text { (1999) }\end{array}$ & + & & + & + & $\begin{array}{l}\text { Renewal \& } \\
\text { Development }\end{array}$ & \\
\hline $\begin{array}{l}\text { Pasher \& Shachar } \\
(2004,2007)\end{array}$ & + & & + & + & $\begin{array}{l}\text { Renewal \& } \\
\text { Development }\end{array}$ & \\
\hline Malhotra (2003) & + & & + & + & $\begin{array}{l}\text { Renewal \& } \\
\text { Development }\end{array}$ & \\
\hline Bontis (2004) & + & & + & + & Renewal & \\
\hline Węziak (2007) & + & + & & & Renewal & Relation \\
\hline $\begin{array}{l}\text { Andriessen \& } \\
\text { Stam }(2005, \\
2008)\end{array}$ & + & + & & & & Relation \\
\hline $\begin{array}{l}\text { Zespół Doradców } \\
\text { Strategicznych } \\
\text { Prezesa Rady } \\
\text { Ministrów (2008) }\end{array}$ & + & + & & & & $\begin{array}{l}\text { Relation } \\
\text { Social }\end{array}$ \\
\hline $\begin{array}{l}\text { Węziak- } \\
\text { Białowolska } \\
(2010)\end{array}$ & + & + & & & Development & Social \\
\hline $\begin{array}{l}\text { Edvinsson \&Lin } \\
(2008,2011)\end{array}$ & + & & + & + & Renewal & \\
\hline $\begin{array}{l}\text { Phusavat et al. } \\
\text { (2012) }\end{array}$ & + & & + & + & & Innovation \\
\hline $\begin{array}{l}\text { Navarro, Ruiz \& } \\
\text { Peña (2014) }\end{array}$ & + & & & + & $\begin{array}{l}\text { Research, } \\
\text { development, } \\
\text { innovation }\end{array}$ & $\begin{array}{l}\text { Relation or trade } \\
\text { Marketing or } \\
\text { image } \\
\text { Social and } \\
\text { development }\end{array}$ \\
\hline
\end{tabular}

Source: Developed by the authors using Hervas-Oliver et al. (2011), Pasher \& Shachar (2004), Malhotra (2003), Bontis, N. (2004), Andriessen \& Stam (2005, 2008), Zespół Doradców Strategicznych Prezesa Rady Ministrów (2008), Węziak, D. (2007), Węziak-Białowolska, D. (2010), Edvinsson \& Lin (2008, 2011), and Navarro, Ruiz \& Peña (2014).

Human capital can be defined as the "thinking" part of national intellectual capital. This element appears in each of the analyzed conceptual models. Differences in the structure of NIC concern the scope of aggregation and names used for the "non-thinking" part of national intellectual capital within which intangible resources that contribute to the creation of national wealth are identified. 
They constitute the so-called national knowledge resources whose appropriate use determines the wealth of the country. Most of the authors divide "non-thinking" intellectual capital into three components: market capital, process capital, and renewal capital (development and renewal). In contrast, the most expansive division is proposed by Navarro, Ruiz and Peña (2014), who, apart from human capital, define six other components.

To create the current as well as the future wealth of the country, the use of only individual intangible assets is not sufficient. It must be a result of synergy between particular intangible assets of NIC. Proper use of and investing into these resources become an important issue. Creation of a country's wealth also occurs through synergistic integration with other resources making up the financial capital of the country. This means that the competitive advantage of a country is built through a proper allocation of capital resources between the tangible and intangible assets (Michalczuk \& Fiedorczuk, 2017). Hence, some analyzed models include an additional, separate element of financial capital which was deliberately not included in Table 2 to emphasize only the NIC structure. The publications of Andriessen \& Stam $(2005,2008)$ and Węziak (2007) as well as Zespół Doradców Strategicznych Prezesa Rady Ministrów (2008) were the only ones where financial capital did not appear as an individual determinant of the country's wealth. The low frequency with which this element occurred was the reason the authors decided to discuss only intangible factors determining national wealth.

\section{RESULTS}

Based on chosen approaches to the division of national intellectual capital, the authors attempted to develop their own taxonomy. In their view, national intellectual capital reflecting the heterogeneous and complex intangible knowledgebased resources, which create the current wealth of the country and contribute to its future development, build competitive advantages and represent a potential for growth consists of five components illustrated in Figure 1.

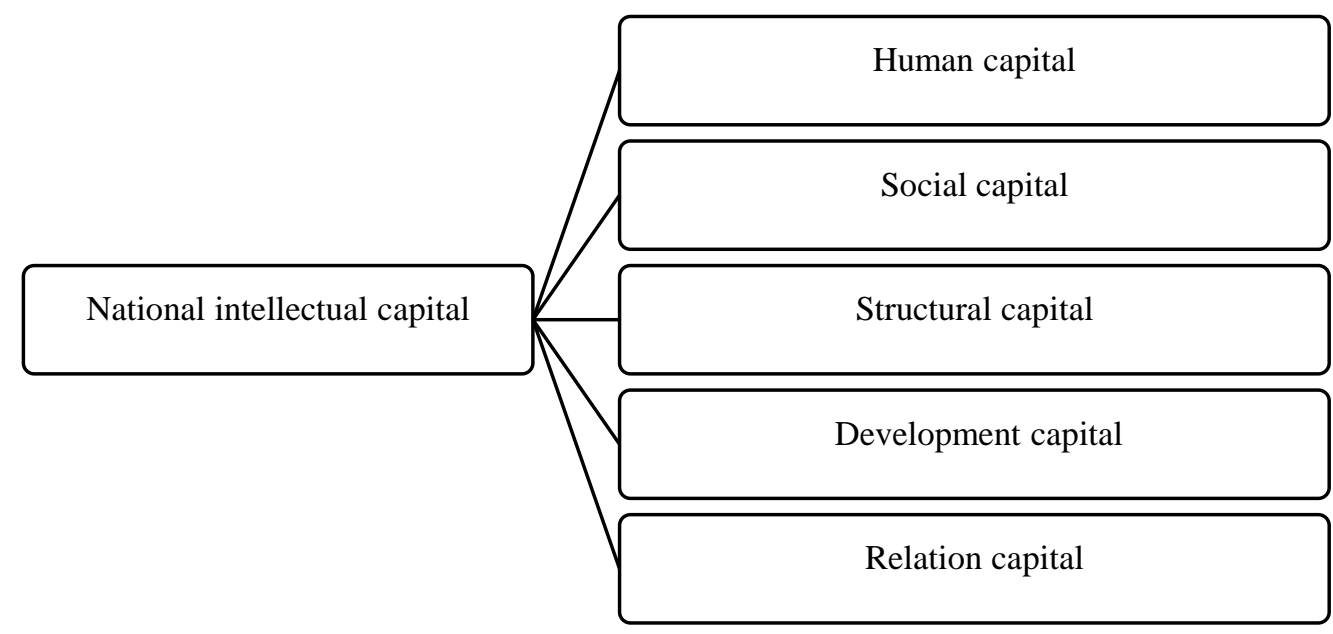

Fig. 1. Structure of national intellectual capital developed by the authors. 
According to the authors of this article, human capital - apart of "thinking" intellectual capital - is an essential component of NIC. It consists of, among others, such intangible resources as knowledge, innate or acquired skills, personal qualities, experience, state of health, the ability to communicate, level of live satisfaction, quality of life, qualifications, and the society's intellectual abilities that determine the realization of national goals. Human capital is the most consistent and significant component of NIC. On the other hand, it is also the least durable element of NIC.

Other selected elements make up the so-called "non-thinking" part of NIC. Social capital is defined as the shared connections and relationships between individuals as well as organizations, institutions, and enterprises. It is a part of public wealth and consists of such intangible resources as the set of informal values and ethical standards, legal norms, social networks determining cooperation, which enable members of a given society to increase the effectiveness of shared activity and more efficient achievement of shared goals. As part of social capital, the authors also classify all non-material parts of heritage, culture and social attitudes towards various issues including environmental problems, tolerance of differences, or equal rights.

Structural capital is identified as the intangible, "non-thinking" macroeconomic resources of the country in the form of knowledge accumulated within infrastructure. Structural capital is co-created by unobservable organizational, communication, social, technological, information and process structures.

Development capital is the future intellectual potential of the country, which reflects the capacity of the economy to continuously create competitive advantages that will ensure a sustainable growth of wealth. It depends on the ability of the nation to be creative and produce new knowledge. It consists of intangible resources such as the number of patents and scientific publications, innovation, spending on research and development and higher education, as well as the level of primary, secondary and higher education.

Relation capital is the value inherent in the country's external relations, connections facilitating cooperation, the attractiveness and competitiveness of the economy, the country's image in the eyes of its partners, investors and individuals. Relation capital can be assessed in regard to the country's international integration as well as its internal and external activity.

According to the authors, it is particularly important to distinguish the importance of social capital within NIC taxonomy. It is relatively rarely identified as a separate component of national intellectual capital, and in the works analyzed by the authors, it was listed as a component of NIC in only three works: the report concerning Polish intellectual capital (Zespół Doradców Strategicznych Prezesa Rady Ministrów, 2008), the study of Węziak-Białowolska (2010), and, together with the environmental aspect of NIC, in the work of Navarro, Ruiz and Peña (2014). However, in the last case, the socio-environmental component has a different meaning than the concept of social capital. Socio-environmental capital refers to the social obligations of the state in relation to the citizens' quality of life, environmental issues, and sustainable development (Navarro, Ruiz \& Peña, 2014). 
In the opinion of the authors of this article, social capital is an element that is crucial in the effective use of human capital. Non-codified standards of conduct often determine the strength of relationships and attitudes toward cooperation. Social capital acts as a connection between individuals deciding the relationship's durability. Adequate social capital, therefore, facilitates activity and binds the nation's relationships (Michalczuk \& Fiedorczuk, 2017).

\section{CONCLUSION}

The development of the concept of knowledge-based economy underlined the significance of intangible assets in relation to the national economy. It turned out that financial capital is not the only factor that determines their value. More and more often it is the intellectual capital, which is becoming the aspect that is responsible for their generation.

The growing importance of national intangible resources in the process of generating value (the country's wealth) should revolutionize the assessment of economies and illustrate the need to manage national intellectual capital. This is the reason that a measurement based not only on financial capital but also on intellectual capital should become the new approach to the evaluation of national wealth. However, the introductions of such a measure will require not only the formulation of a universal and commonly acceptable definition of NIC but a proper taxonomy as well. In recent years, a number of concepts concerning the division of NIC have been created with new ones constantly appearing. Although they differ, they also contain common features. Every model considers human capital to be a primary component of intellectual capital within the macroeconomic perspective that determines the quality of all other components. This diversity of approaches to the taxonomy of national intellectual capital is determined by the fact that, in most cases, they are modifications or improvements of existing definitions (Michalczuk, 2013). Presented approaches to the taxonomy of NIC do not exhaust the entire spectrum of proposals that have emerged in this regard. However, they show the complexity of this kind of capital and its heterogeneous character. More and more complex models of national intellectual capital are being developed - ones that try to organize and classify the scattered and often unknown intangible generators of national wealth. Increasingly more specific functional-resource spheres of a country have been created as part of NIC. Despite the work concerning national intellectual capital, which has been going on for many years, it has not been possible to develop a universal NIC taxonomy.

\section{REFERENCES}

Amidon, D. M. (2002). The Innovation Super Highway. Boston: Butterworth-Heinemann.

Andriessen, D. \& Stam, C. D. (2005). Intellectual Capital of the European Union. McMaster World Congress on the Management of Intellectual Capital and Innovation, 19-21 January 2005. Hamilton, Ontario, Canada.

Andriessen, D. \& Stam, C. (2008). Intellectual Capital of the European Union 2008: Measuring the Lisbon Strategy for Growth and Jobs. Journal of Knowledge Management, 7(4), 489-500. Retrieved from file:///C:/Users/User/Downloads/ejkm-volume7-issue4-article200.pdf 
Bontis, N. (2004). National Intellectual Capital Index. A United Nations Initiative for the Arab region. Journal of Intellectual Capital, 5(1), 13 - 39. https://doi.org/10.1108/14691930410512905

Brennan, N. \& Connell, B. (2000). Intellectual Capital: Current Issues and Policy Implications. Journal of Intellectual Capital, 1(3), 206 - 240. https://doi.org/10.1108/14691930010350792

Edvinsson, L. \& Lin, C. Y. Y. (2008). National Intellectual Capital: A Comparison of the Nordic Countries. Journal of Intellectual Capital, 9(4), 525 - 545. https://doi.org/10.1108/14691930810913140

Edvinsson, L. \& Lin, C. Y. Y. (2011). National Intellectual Capital: A Comparison of 40 Countries, New York: Springer Science + Business Media. https://doi.org/10.1007/978-1-4419-7377-1

Edvinsson, L. \& Lin, C. Y. Y. (2012). National Intellectual Capital Model and Measurement. Journal of Knowledge-Based Development, 3(1), 58 - 82. https://doi.org/10.1504/IJKBD.2012.045570

Edvinsson, L. \& Malone, M.S. (1997). Intellectual Capital Realizing Your Company's True Value by Finding Its Hidden Brainpower. Harper Business, New York.

Fiedorczuk, J. \& Michalczuk, G. (2016a). National Intellectual Capital (NIC) - Conceptualization of Approaches. Prace naukowe Uniwersytetu Ekonomicznego we Wroctawiu, 449, 404-411. https://doi.org/10.15611/pn.2016.449.36

Fiedorczuk, J. \& Michalczuk, G. (2016b). Significance of Skandia Achievements in the Development of Approaches to Conceptualization and Assessment Models of National Intellectual Capital. Optimum, 83(5), 17 - 30. https://doi.org/10.15290/ose.2016.05.83.02

Hervas - Oliver, J., Rojas, R., Martins B. \& Cervelló - Royo, R. (2011). The Overlapping of National IC and Innovation Systems. Journal of Intellectual Capital, 12(1), 111-131. https://doi.org/10.1108/14691931111097935

Käpylä, J., Kujansivu, P., \& Lönnqvist, A. (2012). National Intellectual Capital Performance: a Strategic Approach. Journal of Intellectual Capital, 13(3), 343 - 362. https://doi.org/10.1108/14691931211248909

Labra, R., \& Sanchez, M. P. (2013). National Intellectual Capital Assessment Models: A Literature Review. Journal of Intellectual Capital, 14(4), 582 - 607. https://doi.org/10.1108/JIC-11-2012-0100

Malhotra, Y. (2003). Measuring Knowledge Assets of a Nation: Knowledge Systems for Development. United Nations Advisory Meeting of the Department of Economic and Social Affairs Division for Public Administration and Development Management, 3, 23-25. Retrieved from $\mathrm{http} / / / \mathrm{km}$. brint.com/KnowledgeManagementMeasurementResearch.pdf

Michalczuk, G. (2013). Intangible Assets as a Factor of Company Value. Information Gap of Financial Reporting. Białystok: Bialystok University.

Michalczuk, G., \& Fiedorczuk, J. (2017). Analysis of Conceptualization and Taxonomy of Division of National Intellectual Capital (NIC). In M. Wypych, I. Gawryś, \& P. Trippner (Eds.) Practical and Theoretical Issues in Contemporary Financial Management (pp. 213-223). Lodz-Warsaw: University of Social Sciences.

Navarro, J. L. A., Ruiz, V. R. L., \& Peña, D. N. (2014). Economic Growth and Intangible Capitals: Europe versus Asia. Panoeconomicus, 61(3), 261-274. https://doi.org/10.2298/PAN1403261N

Pasher, E., \& Shachar, S. (2004). The Intellectual Capital of the State of Israel, Our Competitive Advantage The Hidden Values of the Desert. Retrieved from file://C:/Users/User/Downloads/TheIntellectualCapital114.pdf

Pasher, E., \& Shachar, S. (2007). The intellectual capital of the state of Israel. 60 years of achievements. Retrieved from http://economy.gov.il/RnD/Documents/intellectualcapital.pdf

Phusavat, K., Comepa N., Sitko-Lutek A., \& Ooi K. B. (2012). Intellectual Capital: Implementation for Industrial Competitiveness, Industrial Management \& Data Systems, 112(6). 866-890. https://doi.org/10.1108/02635571211238491

Rembe, A. \& ISA (1999). Invest in Sweden, Agency Annual Report.

Stenfent, C. et al. (1996). Welfare and Security for Future Generations, Market Academy, Stockholm University, Stockholm.

Węziak, D. (2007). Measurement of national intellectual capital: application to EU countries. IRISS Working Paper Series, 2007-13.

Węziak-Białowolska, D. (2010).The Intellectual Capital Model of the Region. Concept of Measurement and its Application. Warsaw: Warsaw School of Economics.

Zespół Doradców Strategicznych Prezesa Rady Ministrów. (2008). Report on the intellectual capital of Poland. Retrieved from http://kramarz.pl/Raport_2008_Kapital_Intelektualny_Polski.pdf 


\section{AUTHORS' SHORT BIOGRAPHIES}

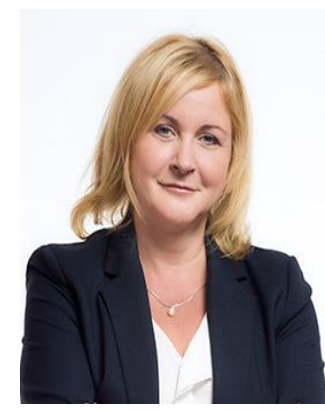

Grażyna Michalczuk is Professor at the Faculty of Economics and Management of the University of Bialystok (Poland). She received the Ph.D. degree in economy from the University of Bialystok in 2000. Her research interests include financial reporting of intangible assets.

E-mail: g.michalczuk@uwb.edu.pl

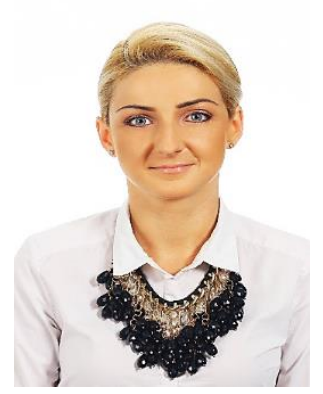

Julita Fiedorczuk, M.A., is a Scientist at the Faculty of Economics and Management of the University of Bialystok (Poland). She is currently a Ph.D. student. Her research interests include national intellectual capital. E-mail: fiedorczukjulita@uwb.edu.pl 